\title{
The Rise of the French Doctrine of Informed Consent: Criminal Responsibility for an Unauthorised Medical Experiment - The Case of the Antiquaille Hospital and Subsequent Notable Judgments
}

\begin{abstract}
By Anatoliy A. Lytvynenko*
The French doctrine regarding a patient's informed consent has a long and very rich history, dating back at least to the mid-nineteenth century. Medical malpractice had become a frequent subject of criminal trials and civil litigation against physicians and surgeons in the nineteenth and early twentieth centuries, resulting in French medical case law and its academic scholarship becoming one of the most prominent throughout all the civil law jurisdictions. Simultaneously, medical malpractice lawsuits were not rare in civil or common law jurisdictions. The uniqueness of French jurisprudence lies in the development of a robust body of case law, which formed the basis for patients' rights, and specifically informed consent and the right to medical data confidentiality. The right to informed consent is a reflection of the patient's right to their own bodily integrity, which may not be violated for the purpose of treatment, except in an emergency. Moreover, the rule of consent is even stricter if physicians are administering experimental treatment (which is not generally banned, as it may benefit the patient), or conducting certain methods of treatment for purely scientific purposes - as was in the case of the Antiquaille Hospital in Lyon, where a dangerous and experimental method of treatment was used to treat a ten-year-old minor suffering from dermatophytosis, which was not authorised by his guardians. The case, which was adjudicated by the criminal court of Lyon, is historically one of the first legal cases to deal with unconsented treatment conducted for the purpose of a scientific experiment. Over the twentieth century, similar legal cases became more frequent in France.
\end{abstract}

Keywords: informed consent, medical experiments, patient autonomy, right to bodily integrity, medical law, French law.

\section{Introduction}

The responsibility of physicians and hospitals for actions of malpractice is one of the oldest topics of medical law, based on the commonly accepted tenet that a patient has a right to seek legal redress from a physician and/or the hospital for damage, based upon the contract or tort between the two parties. At the same time, during the nineteenth century the patient-physician relationships remained quite

*Doctoral student at Baltic International Academy, Riga, Latvia (Department of Legal Sciences); Doctoral student at the School of Law at the Robert Gordon University of Aberdeen 
paternalistic, and occasionally the courts were even unable to reach a proper conclusion regarding the characteristics of the patient-physician relationship. ${ }^{1}$ Nineteenth-century French legislation did not provide any special liability of doctors and nurses (except for the Professional Secrecy Obligation, protected under Art. 378 of the Penal Code), and general malpractice terms were attributed to them. ${ }^{2}$ During earlier periods, they could be found guilty of Art. 311 or 319/320 of the Penal Code, but later the courts primarily attached civil liability on the basis of Art. 1382-1383 of the French Civil Code, which was attributed to more "moderate" negligence. ${ }^{3}$ In order to be found criminally negligent, the physician's negligence had to involve gross disregard of the existing rules of the medical profession and the patient's health condition, causing serious injuries to the patient, displaying ignorance that is incompatible with the possession of a doctor's diploma. ${ }^{4}$ Despite French courts have firmly affirmed that doctors are liable for their malpractice from a relatively early date, ${ }^{5}$ the jurisprudence relating to medical liability during the Regime Ancien did not form an adequate body of case law (some parliaments could find a doctor liable for negligence or application of dangerous methods of treatment, while the others found that physicians could not be liable for negligence or medical errors occurring in the course of practicing their profession). ${ }^{6}$ However, the inconsistence in the courts' position relating to the issue of doctor's liability, as such, was entirely abandoned in the first decades of the nineteenth century - medical practitioners, nurses and midwifes could be found to be liable for negligence, had they been in fault. Receiving compensation for a doctor's faulty actions (even in cases which resulted in a conviction and included a fine and occasionally several days of imprisonment) did not create any actual rights for the patient, at least not as we define patients' rights at present. In fact, patients' rights as we know them today could only develop from malpractice actions involving the patient's will. In 1982, the Federal Supreme Court of Germany, adjudicating a case concerning the plaintiff's right to access his medical record, claimed that the patient should not be regarded as a mere object of treatment, ${ }^{7}$ a foundational idea upon which the doctrine of patients' autonomy is based.

Since we are dealing with a very unusual case, I would rephrase this claim in the following way: the patient should not be regarded as a mere object of treatment in the course of a scientific experiment. Experimental treatment methods could be applied if they are highly likely to benefit the patient, and if the development of medical science is contingent on the implementation of experimental methods, but they should be reconciled with the patient's will, or "informed consent," as it became known by the mid-twentieth century. Long before the case of Salgo $v$.

\footnotetext{
${ }^{1}$ Reichsgericht, III Strafsenat, Urt. v. 31.05.1894.

${ }^{2}$ Morin (1856) at 192-193.

${ }^{3}$ See, e.g. $X$. c. $B$.

${ }^{4}$ Peyronnette c. Dr. Cormon.

${ }^{5}$ The 1830 case of Foucault c. Helie was reported also in Labraque-Bordenhave (1879) and in Briand, Chaude \& Bouis (1869); as well as in Dalloz Methodique, Vol. XXXIX (39), at 316-317

${ }^{6}$ Labraque-Bordenave (1879) at 196-197

${ }^{7}$ Bundesgerichtshof, 23.11.1982; VI ZR 222/79, para. 15-16.
} 
Leland Stanford etc. Bd. Trustees (1957) was adjudicated, ${ }^{8}$ French courts were using the terms "a duty to warn"9 (referring to the doctor's duty to warn patients of the possible consequences of a certain method of treatment), or a "free and informed consent $" 10$ (referring to the requirement that the patient's consent be obtained before any medical intervention, including clarification of the planned procedure and, occasionally, its possible negative implications). A "duty to warn" is mentioned and discussed by Rene Demogue in his sixth volume on the treaty of obligations, which confirms the fact that the natural elements of informed consent were not only known in occasional court reports, but in respected legal doctrine as well. ${ }^{11}$ In his doctoral thesis on the civil liability of the physicians, Abel also discusses the doctor's obligation to warn the patient of the hypothetical hazardous effects of a potentially dangerous medical intervention, referring to the existing case law in order to provide examples of how the courts dealt with the issue at the time. ${ }^{12}$ based on these books, we may conclude that by the first part of the twentieth century, French medical law was an elaborate body of doctrine, law and jurisprudence and already possessed all the concepts of contemporary medical law.

The French counterparts of the Salgo case are considerably older, and the wording of the court reports lead to the conclusion that the French courts did not directly refer to a basic consent to medical intervention (predominantly, a surgical one), but rather to a far more "intelligent" one, in the same fashion as the California Court of Appeals did several decades later. The case I am referring to, the trial of Guyenot and Gailleton (as entitled in the official court report), ${ }^{13}$ known also in Boucard's brochure of the case materials as "The Case of the Antiquaille Hospital," was adjudicated in 1859 by the criminal court of Lyon, contributed much to the French doctrine of informed consent. The case of Dechamps (188990), adjudicated first by the civil court of Liege, Belgium and appealed at the Court of Appeals of Liege, provided the next milestone judgment on this matter. ${ }^{14}$

\section{Aims of the Paper and Research Methods}

Although the judgment at the core of this paper is quite old, it perfectly illustrates the uniqueness of the French medical jurisprudence at its beginning, as it already provided a legacy not only on the subject of informed consent, but also on the issue of unauthorised medical experiments. This was very unusual for nineteenth-century case law, which provided the basis for medical law. Thus, this paper strives to acquaint the reader with the vaults of French medical law and the inception of the concept known as the patient's rights, which developed from a resonant judgment handed down in Lyon. This is arguably the first medical malpractice case featuring an experimental method of treatment that was applied

\footnotetext{
${ }^{8}$ Salgo v. Leland Board etc. Trustees.

${ }^{9}$ Chini c. Coconni; B. c. G..

${ }^{10}$ Consorts Chavonin c. K.; L. c. Consorts Chavonin et Cie des produits chimiques de la Sorbonne.

${ }^{11}$ Demogue (1932) at 186-187 (Ch. 1)

${ }^{12}$ Abel (1936) at 123-134.

${ }^{13}$ Min. Publ. c. Guyenot et Gailleton.

${ }^{14}$ Demarche c. Dechamps.
} 
solely for the necessity of medical science, and published in a professional scientific journal. I use the term "arguably" as an earlier English case, known as Slater v. Baker and Stapleton, had some similar characteristics, but is also considerably different, since the defendants rebroke the plaintiff's leg to apply a new means of treatment, and not for the specific purpose of publishing their new method of fracture treatments in a scientific article. ${ }^{15}$ Thus, the "Case of the Antiquaille Hospital" may be rendered as the first case regarding an unauthorised medical experiment, conducted solely for the advancement of medical science.

This paper follows a historical-legal approach, and discusses a historical judgment that had a considerable impact on the future developments of French medical law and the evolution of pattients' rights. Historical jurisprudence should never be underestimated, as the foundation of the patient's rights is stringently valuable for the concept of the patient's autonomy and its vaults.

\section{Literature Overview}

"The Case of the Antiquaille Hospital" was not only featured in a court report in Dalloz Periodique, in which most of French (and occasionally foreign) judgments were published, ${ }^{16}$ but was discussed in a brochure published by Boucard (1860), featuring additional facts regarding the case, including the speeches of the Attorney General (Avocat Imperiale) and counsel for defendant. ${ }^{17}$ The journal Revue de Therapeutique médico chirurgicale (1860, [1]) also featured a paper containing the minutes of the case and the defence counsel's argument. ${ }^{18}$ This judgment has been mentioned throughout the modern literature on the subject, for example in the works of Monnier ${ }^{19}$, Azenkot ${ }^{20}$, Beviere-Boyer in his work on medical research involving minor patients, ${ }^{21}$ Memeteau ${ }^{22}$ and Bernelin in her doctoral thesis. ${ }^{23}$ Regrettably, the case facts and the judgment materials were not illustrated in the aforementioned works in much detail. It is this lacuna that the present paper will attempt to fill.

In their discussions of medical law, neither Boucard's contemporaries nor the next generation of French legal authors alluded to this judgment within the context of the civil or criminal liability of doctors and other medical staff for harming their patients. For instance, Labraque-Bordenave (1879) mainly discussed the "Domfront case" 24 and the responsibility of the physicians in the times of the Ancien Regime, where the existing case law was frequently inconsistent and the

\footnotetext{
${ }^{15}$ Slater v Baker \& Stapleton.

${ }^{16}$ Min. Publ. c. Guyenot et Gailleton.

${ }^{17}$ Boucard (1860).

${ }^{18}$ Anonymous (1860).

${ }^{19}$ See Monnier (2001) at 383-402, and 385-386.

${ }^{20}$ Azenkot (2001).

${ }^{21}$ Beviere-Boyer (2010) at 32.

${ }^{22}$ Mémeteau (2012).

${ }^{23}$ Bernelin (2017) at 67.

${ }^{24}$ It is a nickname for the case of Foucault c. Helie. This judgment was not once mentioned by contemporary authors.
} 
courts did not always acknowledge that physicians could be liable for negligence. ${ }^{25}$ Labori, Schaffhauser \& Duparcq mentioned the case in a treatise on criminal law while examining the issue of the victim's consent to a crime committed against her. ${ }^{26}$ Demogue cites this judgment in his discussion of the liability of physicians whose acts, involving a dangerous medical intervention, are not aimed at curing the patient, but rather at "removing a physical imperfection." He refers to "The Case of the Antiquaille Hospital," claiming: "It is still the same if the physician indulges in hazardous [clinical] trials, not to cure, but for the purpose of study [i.e. research]." 27 The case was also briefly mentioned in Petit's paper on medical liability. ${ }^{28}$

Finally, it is important to note that the case note of the Dechamps appeal in 1891, also appearing in the Dalloz Periodique, discusses the case under discussion, citing earlier examples of medical malpractice cases where the consent of the patient was the main issue or was implicitly meant to be as such. ${ }^{29}$

\section{Case Facts}

In early December 1858, a 10-year-old (11 according to Boucard's brochure) minor, identified by the initial B. (the court report in Dalloz Periodique used the name 'Bouyon'), entered the Antiquaille hospital in Lyon to be treated from dermatophytosis, affecting his entire scalp. He was conservatively treated for a period of a month, without success. On January 7, 1859, Guyenot, a young intern at the venereal department, asked Gailleton, the head of the department, for permission to give the boy a "syphilitic" inoculation, which was an inoculation consisting of a mucoid plaque. The head of the department authorised him to do so, and later he administered four injections to the patient's right arm. No result was seen until February, when two superficial ulcerations ( $2 \mathrm{~mm}$ in diameter) appeared, and in March roseola appeared on the boy's trunk. An anti-syphilitic treatment was instituted, but the symptoms disappeared after six days (or around ten days, according to the trial brochure), and the anti-syphilitic treatment was terminated. By April, the boy's condition improved. The boy felt good and the ringworm disappeared by August. The experimental method of treatment was described by Guyenot in a weekly Paris newspaper (Gazette hebdomadaire de Paris, 15 Avril 1859). The young doctor claimed that the boy was not hurt by the procedure and was doing well.

The public prosecutor learned of this errant procedure and instituted proceedings for battery. He stated that the procedure had been implemented strictly out of pure scientific curiosity. M. Roe, the Imperial Advocate, claimed that while the right to experiment with healing methods was acceptable, it should

\footnotetext{
${ }^{25}$ Labraque-Bordenave (1879).

${ }^{26}$ Labori, Schaffhauser \& Duparcq (1896) at 609 (para. 55-56).

${ }^{27}$ Demogue (1932) at 186-187.

${ }^{28}$ Petit (1912) at 139.

${ }^{29}$ See the case report of Dechamps c. Demarche in Dall. Per. 1891 II 281. Note that both the first and second-instance court reports with supplementary notes were published in diverse books and periodicals, and the supplementary note text also varied.
} 
only be applied in order to advance a patient's recovery: "such as an employment of a new [treatment] method when all the other means have been employed." The advocate also believed that possession of an advanced scientific title (e.g. a doctorate) was required in order to administer an experiment legitimately. Lastly, the advocate claimed that when an experiment has another goal other than just treating the patient's condition, the patient's consent must be obtained. ${ }^{30}$ After having stated these assumptions, the Imperial Advocate reproached the accused Guyenot for experimenting without possessing a scientific doctorate and without having an actual goal to cure the patient. The Public Prosecution found that the doctor's acts contained elements of wilful injury - either by administering the injection itself or based on its consequences. ${ }^{31}$ the Imperial Advocate assumed that the defence might claim lack of malice (which he objected to in his position later) and added that this failed to take into account the position of the patient, who was not interested in participating in such an experiment. Thus, the Imperial Advocate claimed that by conducting such an experiment, Guyenot was attempting to augment his medical reputation rather than acting in the interest of the patient. He also stated that the senior physician, Gailleton, was complicit in the offence, as he knowingly allowed the young doctor to conduct such an experiment on a child under his care.

\section{The Position of the Counsel for Defendant}

According to Boucard's Brochure, Mr Royer, counsel for defendants, put up various arguments. ${ }^{32}$ First, the counsel presented a consultative summary endorsed by three surgeons and the Head of the Hospitals from Lyon, as well as two Antiquaille doctors. The summary claimed that the eleven-year-old boy entered the hospital with dermatophytosis, covering the entire scalp, which had lasted several years. The doctors claimed that the minor was in a state of chloroanemic cachexia and debility, suffering from mycobacterial cervical lymphadenitis, but after a course of treatment he gained weight and his health gradually improved. The summary also reiterated the course of treatment after the inoculation (see above). The doctors considered the boy's health as "flourishing" and simply incomparable to his previous condition of health, and they found the treatment to be successful, stating that it was not possible to have restored the boy's health "better or quicker." According to Royer, the treatment process lasted eight months and its results were exceptional. He also claimed that the doctors' acts should not be considered to be "assault and battery" and ascertained that it was absurd to speak of any malice on the part of the doctors. Regarding the patient's consent, Royer said that Mr Gailleton believed that "this consent is, in reality, illusory; that the patient of the hospital will always consent to what [treatment] is offered to him - without any [possibility] to be able to calculate the consequences ... let him trust

\footnotetext{
${ }^{30}$ Boucard (1860) at 4; Dall. Per. 1859 III 87, p.p. 87-88

${ }^{31}$ Boucard (1860) at 4; Dall. Per. 1859 III 87, 87-88

${ }^{32}$ Boucard (1860) at 6 et seq., Dall. Per. 1859 III 87, 87-88
} 
in the science of the doctor. ${ }^{133}$ The counsel for the defendants concluded that 1) the treatment was harmless; 2) the treatment by analogy was applied; 3) the result was highly efficient. He pleaded for acquittal. ${ }^{34}$

\section{The Judgment and the Court's Inferences}

The court discussed the main facts of the case and summarised the position of the counsel for the defendant as follows: 1) the incriminating facts, upon his view, do not constitute an offence; 2) the means applied by the doctors were not purely for experimental purposes, as primarily they wished to cure the patient, and only as an incidental aim, to resolve a controversial issue of medicine. 3) the doctors had no malicious intent and did not wish to harm the boy. The court responded to these issues as follows:

1. The law applies a generic definition in order to define an act of "battery." This includes any lesion, even a small one such as the prick of a needle, affecting an individual's body.

2. The rights and obligations of the doctors towards science have their limits, and should never come before the rights of the patient. It is acceptable for the physician to treat the patient with a new method, if curing the patient is the only goal of applying the experimental method of treatment. The court, however, did not find that this was the situation in this case. The court believed that the doctors' main goal was to resolve a medical question by means of an experiment, seeking to determine if the manipulation they performed could possibly lead to a cure. The court also recalled that Guyenot admitted that he could not predict the results of the inoculation he had administered. Therefore, the Court inferred that the defendants could not maintain that they wanted to treat the patient by a curative method, of which they were not convinced themselves.

3. The Court stated that it is not necessary for the offender to act maliciously or with hatred and revenge in order for his actions to constitute an offence. In this case, it was sufficient for the defendants to act knowingly, attempting to resolve a scientific issue by taking the risk of causing harm (which obviously existed). The Court also noted that analogous experimental treatment, if carried out elsewhere, would not legitimise what had occurred at the Lyon hospital. The court found Guyenot and Gallieton liable - Guyenot for battery (Art. 311 of the Penal Code) and Gailleton for complicity. They were fined FRF100 and FRF50 respectively. ${ }^{35}$

According to the Dalloz Periodique (Vol. 1859, p. III), the general guidelines resulting from this case are as follows:

\footnotetext{
${ }^{33}$ Boucard (1860) at 12

${ }^{34}$ Boucard (1860) at 13-14

${ }^{35}$ Dall. Per. 1859 III 87, 87-88
} 
1. The court may presuppose that any lesion caused by a surgical instrument that affects the patient's body or health, even slightly, constitutes an "injury" (Art. 311 of the Penal Code). This includes an injection or its consequences. $^{36}$

2. To establish the criminal character of the battery, it is not necessary for the health care provider to act with malice, revenge or hatred. It is sufficient that 1 ) he acted without a right to do so; 2) he acted with full knowledge of the facts; 3) he acted with a specific aim to conduct a scientific experiment.

3. The provisions of the criminal code attributed to assault and battery could be applied in this case (as a "casuistic" interpretation).

4. Consent of the person to an act of battery, in any form, does not exonerate the health care provider.

5. Physicians may use experimental curative methods only for the treatment of patients, and not for the purpose of resolving a specific medical question. Depending on the circumstances of the case, such action may give a rise to a lawsuit for battery.

\section{Aftermath}

Another important milestone of the French law regarding patients' rights is the case of Dr Dechamps (1889-1890). A three-year-old child with a leg curvature was brought to a Liege hospital for corrective surgery. The doctor performed an (unconsented, according to the plaintiff) ${ }^{37}$ osteotdalomy, after which gangrene set in, causing the foot's subsequent amputation. Interestingly, the defendant himself did not recommend that such an operation be performed on children under the age of six, which was taken into account by the trial court, though the appellate court claimed that the courts must not interfere in the application of the treatment methods, but should assess the possible imprudence of the doctor. ${ }^{38}$ Having lost at the trial court, Dechamps appealed, claiming he could prove that the child's relatives had given their consent to the procedure, and he was not at fault. The respondent also claimed that the operation was badly performed, and the gangrene occurred owing to negligent postoperative care. Before allowing the appeal lodged, the court let the litigants to prove their claims by witness testimony. ${ }^{39}$ This judgment elaborated on or confirmed a number of principles:

1) Surgery performed on a patient is valid only upon his own consent, and where a patient may not consent due to being incapable of doing so, upon the authorisation of his legal representative or guardian.

2) Consent is not required in urgent situations.

\footnotetext{
${ }^{36}$ See also Boucard (1860) at 4.

${ }^{37}$ Dechamps c. Demarche.

${ }^{38}$ See the case reports in: Dall. Per. 1891 II 281, 282 and Recueil Sirey 1895 II 237, pp. 237-238 (featuring the Dechamps case report in a different judgment case note, and a trial/appellate court report synthesis in Dall. Per. 1891 II 281, p. 281-283).

${ }^{39}$ Belgique Judiciaire 1891.699, at p. 701; Dall. Per. 1891 II 281, 283
} 
3) The physician does not need to go into details concerning the technical features of the operation, it is enough for him to give a short explanation of the name of the procedure/operation, and the reason it is being performed (later, however, French courts extended this rule).

4) If a patient seeks advice for medical assistance, or is admitted to a hospital, it does not mean that he automatically consents to all treatment and procedures that a doctor may advise him to undergo.

5) The physician is not liable for applying any method of treatment, and the courts should not interfere in this aspect; the doctor is liable for imprudence or carrying out his duties contrary to the rules of the medical profession, and the courts are to assess this imprudence, had it occurred. ${ }^{40}$

Dechamps was the first of a chain of cases, where the lack of a patient's consent (and frequently, the failure of the doctor to warn the patient of the possible consequences of a surgical operation, manipulation or specific treatment procedure) constituted acceptable grounds for commencing a medical malpractice action based on Art. 1382-1383 of the Civil Code. In fact, experimental methods of treatment, though not always being purely scientific experiments, resulted in a multitude of legal actions against physicians, with diverse outcomes.

The Antiquaille Hospital Case had a substantial impact on the further development of jurisprudence on the subject of patients' rights. The judgment is stringently cited in the Dalloz. Periodique (Vol. 1859), Part III note on the Dechamps appeal, ${ }^{41}$ whereas the Journal des Tribunaux version of the trial's court report refers only to Belgian precedents, none of which involved the issue of unconsented surgery. ${ }^{42}$ Tart (1894) made a number of statements regarding the patient's consent and the issue of experimental treatment (even though the text mainly concerned Dechamps and did not cite The Antiquaille Hospital Case directly): "A doctor does not have the right to carry out experiments upon his patient. In order to [emphasise] this, I mean that any experimental research for the purpose of curiosity or scientific interest, is strictly prohibited. The patient's health is the measure of both the doctor's rights and his duties. The doctor's exclusive mission is to try to heal [the patient]; any act which goes beyond this limit becomes immediately illegal, and must be avoided."

Tart emphasised that the doctors may use experimental methods of treatment if these could benefit the patient, and even relatively dangerous methods of treatment and medications could be justifiably applied in the course of healing, if they are implemented to save the patient. ${ }^{43}$ The allusion to any experimental treatment implemented for the sole aim of conducting research is sufficiently comparable to The Antiquaille Hospital Case, as the defendants were convicted of exactly such acts.

Tart's position, and the position of the Lyon criminal court in the case of the Antiquaille Hospital, was upheld in both doctrine, jurisprudence and the judgment

\footnotetext{
${ }^{40}$ See summary of the Dechamps case facts reported in: Dall. Per. 1891 II 281

${ }^{41}$ See report of the Dechamps appeal in Dall. Per. 1891 II 281, 281-282

${ }^{42}$ See the Dechamps case report in Journal des Tribunaux (Bruxelles) Vol. IX (1890) at 5-7

${ }^{43}$ Tart (1894) at1070-1072.
} 
notes supplied in periodicals. It was commonly known that a physician may not use his patient as a "test subject," as doing so would construe civil liability. ${ }^{44} \mathrm{~A}$ very interesting case occurred in France in the 1930s, featuring a wrongful death suit brought by the heirs of Pierre Chavonin, who sued the defendant, Dr L., for negligence. Pierre Chavonin, ${ }^{45}$ who suffered from obliterating arteritis, came to the defendant in December 1932 for a consultation. Following, he recurrently underwent radiotherapy treatment until May 1933. In November 1933, Chavonin was summoned to the hospital again, though the purpose of this visit is unclear. According to the facts, Dr L. was visited by two interns who were studying the diagnostics and treatment of obliterating arteritis by means of arteriography, and they asked him if he knew of any patients suffering (or who had suffered in the past) from the said ailment. He told them that he treated Chavonin around a year earlier, and that Chavonin was about to come to the hospital. The expert conclusions following Chavonin's death stated that he had not requested medical care nor a medical examination since May 1933, and was summoned to the hospital by Dr L only at the request of the two abovementioned interns, "in order to serve as a subject of observation for the said specialists." Their experiment failed and had fatal consequences. A short while after he visited the hospital, Chavonin developed severe pains and later gangrene, resulting from the obliteration of the artery where they injected the opaque. The patient died in the first days of December 1933. Later, Dr L. alleged that the gangrene developed as a consequence of the ailment Chavonin was suffering from earlier, in 1932-1933, ${ }^{46}$ but the experts' conclusion stated there was a causal link between Chavonin's death and the experiment that the interns had conducted on him.

The court determined that under the doctrine established by case law and literature, a doctor who experiments with a remedy or new method of treatment on a patient unnecessarily and without his free and informed consent, is committing professional misconduct. Dr L. summoned Chavonin to undergo radiography, a procedure that did not involve anything hazardous to his health, and did not mention an injection of opaque (which is used for performing arteriography). Nor was it established that the two young men, the interns, had expressed to Chavonin their intention to conduct the medical experiment, or warned him of its possible dangers, or even merely obtained his consent. Dr L. admitted to being at fault for everything that had occurred and did not argue that he was not responsible for the acts committed by the interns. He also did not deny that he had summoned Chavonin to the hospital in order to facilitate the research of the two interns. The court also found that the interns had committed a fault by conducting such an experiment, which Chavonin had never requested nor agreed to, nor was it necessary for him to undergo. Dr L. was found to be responsible for the death of the patient and required to pay out FRF100,000 in damages. ${ }^{47}$ The doctor filed an

\footnotetext{
${ }^{44}$ See, for instance, Epoux R. c. Docteur P.

${ }^{45}$ As it was later revealed by the court, Chavonin was an employee of an industrial firm, married, and a father of five, two of which were minors at the time of the proceedings. Despite the fact that his exact age was not stated, he seemed to be around 50 years old.

${ }^{46}$ See also the report of the case in Dalloz Periodique (1936), Part. II, p. 9-13, where the details of the autopsy examination are described in detail.

${ }^{47}$ Consorts Chavonin c. $K$.
} 
appeal, which was unsuccessful. The Paris Court of Appeals confirmed the facts established by the court of Seine, i.e. that Chavonin was in relatively good health after he received treatment in early 1933 and did not require any medical treatment at the time he was summoned to the hospital. The experiment obviously did not have curative goals, but was performed merely for scientific research, and thus the head of the department should be held liable for the incident. ${ }^{48}$ Additional facts and a substantial supplementary note on this judgment can be found in the Dalloz Periodique version of the trial court judgment report. ${ }^{49}$

While previously the term "free and informed consent" ("consentement libre et éclaire") was used in contexts unrelated to medical law, such as issues of marriage, family and contract law, the Chavonin case is the first judgment in which the court used this term in the context of a patient's consent to a surgical or other medical intervention, examination or experiment. Thus, we may determine that "informed consent" in its broad sense (see above) is a French law innovation, established both in case law and doctrine, relating to various aspects of the doctor's duty to inform the patient of the proposed medical treatment, its methods and possible dangerous side effects.

The subject of experiments on humans is still discussed within French case law at present. In a 2012 judgment, the Administrative Court of Appeals of Paris annulled the decision of the Biomedicine Agency allowing the National Institute of Health and Medical Research to implement a research protocol on embryonic stem cells used for modelling facio-scapulo-humeral muscular dystrophy. This was because it was not established that there was no alternative method to conduct this research, which was the only justifiable argument that would deem the proposed protocol legitimate. Upon the appeal of Jereune Lejeune Foundation, the Administrative Court of Appeals quashed the judgment of the first-instance administrative court. ${ }^{50}$

\section{Conclusions}

The doctrine of informed consent seems to be well-established and researched. At the same time, there are many rare and lesser-known judgments on the subject, occasionally represented by academic literature. This paper strives to represent an alternate, more civil-law approach to the gist of informed consent and the origination of it in the legal system of France, which, at present, is one of the most elaborate in respect to medical law and the patient's rights, and has been such for over one hundred years. Despite the fact that consent to medical treatment was a rare subject of litigation in the late nineteenth and early twentieth century in countries with a more paternalistic view on medicine, the opposite was true for France and Belgium, where a multitude of medical malpractice cases already existed. The focus of this paper, The Antiquaille Hospital Case, provides an example not only of negligence or assault by implementing an unconsented

\footnotetext{
${ }^{48}$ L. c. Consorts Chavonin et Cie des produits chimiques de la Sorbonne.

${ }^{49}$ L. c. Consorts Chavonin et Cie des produits chimiques de la Sorbonne.

${ }^{50}$ Case nr. 10PA0582.
} 
operation, but deals with an unconsented operation conducted solely for the purpose of a medical experiment on a minor. If we accept that the Fourth Generation of Human Rights in respect to medical law encompasses the issues of medical research and experiments on human beings, then The Case of the Antiquaille Hospital in 1859 may be considered its inaugural event, as the physicians' actions were specifically meant to obtain information within the framework of medical research, which was published in a local scientific journal. While the Chavonin Case (1935-1937) resembles the circumstances of the Case of Antiquaille Hospital in principle, its consequences were more deplorable for the patient. Similar judgments are of great value to the evolution of medical law, especially in civil law jurisdictions. While this paper represents only a fragment of the evolution of the informed consent doctrine in French medical law, the author intends to continue to delve into the doctrine of informed consent in French law, especially regarding Dechamps and the resultant judgments, which provided the basis for the concept of "informed consent" in modern French law.

\section{References}

Abel, B. (1936). La responsabilité civile des Médecins. Ph.D. Thesis. Université de Nancy, Faculté de droit. Nancy, Imprimerie Georges Thomas.

Anonymous (1860). 'Poursuites dirigées contre deux médecins à l'occasion d'inoculation syphilitique' in Revue de thérapeutique medico-chirurgicale pp. 23-28.

Azencot, S. (2001). Le consentement du patient en médecine générale: au-delà de la jurisprudence quelle place en pratique quotidienne. Sciences du Vivant [q-bio].

Bernelin, M. (2017). Les sources du droit de la recherche biomédicale en France et au Royaume-Uni, étude comparative du concept de légitimite / The Regulation of Biomedical Research in France and in the United Kingdom: A Comparative Study of the Concept of Legitimacy. Doctor of Philosophy $(\mathrm{PhD})$ thesis, University of Kent, Université Paris Nanterre, France. [In English \& French]

Beviere-Boyer, B. (2010). L'intégration du mineur au processus décisionnel de sa participation à la recherché, Master 2 "Recherche en Ethique".

Boucard C.-V. (1860). Inoculation d'accidents secondaires syphilitiques: [affaire de l'Hospice de l'Antiquaille]. Lyon.

Briand J., Chaude, E. \& J. Bouis (1869). Manuel complet de médecine légale \& Traité élémentaire de Chimie légale. 5ed. Éditions J. Baillière \& Fils.

Demogue, R. (1932). Traité des obligations en general, Tome VI. Paris: Bibl. A. Roussea [In French]

Labori, F., Schaffhuaser, A. \& A. Duparq (1896). Répertoire Eencyclopédique du droit Français, T. 2. Paris.

Labraque-Bordenave, P. (1879). De la responsabilite des medecins dans la pratique de leur art, France Judiciaire Ann. 1879, p. I, p. 196-200.

Mémeteau, G. (2012). "La loi peut-elle contrôler la validité du consentement?" La lettre del'Espace de Réflexion Éthique, Publication du CHU de Poitiers.

Monnier, S. 2001. La reconnaissance constitutionnelle du droit au consentement en matière biomédicale, Revue internationale de droit compare /Année 2001/53-2 pp. 383-402. [In French] 
Morin, A. (1850). Répertoire général et raisonné du droit criminel: où sont méthodiquement exposées la législation, la doctrine et la jurisprudence, Tome 1. Paris: C.-A. Durand, libraire-editeur.

Petit, M. (1912). 'De la Responsabilite Medicale', Archives d'electricite medicale (25.6.1912). [In French]

Tart, I. (1894). 'De la responsabilite des persones. Art du guerir'. (20 July 1894). La Belgique judiciaire. Gazette des tribunaux belges et étrangers. 1891. Alliance typographique, Bruxelles.[In French]

\section{Cases}

\section{Germany}

Reichsgericht, III Strafsenat, Urt. v. 31.05.1894, Rep. 1406/94 = ERG St. S. Bd. 25. S. $375,380-382$

Bundesgerichtshof, 23.11.1982; VI ZR 222/79, para. 15-16

\section{France}

Chini c. Coconni, Cour d'Appel de Aix, 22 October 1906, Dall. Per. 1907 II 41, $42-44$ and note;

B. c. G., Cour d'appel Douai, 10 juillet 1946, Dall. Ann. 1946.351, 351-353.

Case 10PA0582, Cour administrative d'appel de Paris, 3-ème chambre, 10/05/2012.

Consorts Chavonin c. K., Admin. d'assistance Publique et soc., des laboratoires Thorande, Trib. civ. de la Seine (1 Chambre), 16 mai 1935, Dall. Heb. 1935.390, 390-392; Dall. Per. 1936 II 9 (first instance).

Dechamps c. Demarche, 27 Nov. 1889, Trib. civ. de Liege; Cour d'appel Liege, 30 juillet 1890, reported in: Journal des Tribunaux (Belge) 1890 (Vol. IX), p. 5-7 (trial court report); Revue judiciaire (Lausanne), Anno 1890, p. 85; Pasicrisie 1890 III 83, 8385 (trial court); Pasicrisie 1891 II 78, 78-80 (appeal); Dall. Per. 1891 II 281 (appeal); Recueil Sirey 1895 II 237 (concise case report); Belgique Judiciaire 1890.471 (trial court); Belgique Judiciaire 1891.699 (appeal).

Epoux R. c. Docteur P., Cour d'Appel Lyon, 27 juin 1913, Gaz. Du. Pal 1914 I 506, 506507.

Foucault c. Helie, Trib. civ. de Domfront, 28 septembre 1830, Dall. Meth. Vol. XXXIX (39), at p. 316-317 (printed in 1858).

L. c. Consorts Chavonin et Cie des produits chimiques de la Sorbonne, Cour d'Appel de Paris, 1 Chambre, 11 mai 1937, Dall. Hebd. 1937.340, 340-431 (appeal).

Min. Publ. c. Guyenot et Gailleton, Trib. corr. de Lyon, 15 dec. 1859, Dall. Per. 1859 III 87.

Peyronnette c. Dr. Cormon, Trib. corr. de la Seine, 20 juillet 1907, Pan. Fr. Per. 1910 II $153,153-155$.

X... c. B..., Cour de Cass, Ch. Req., 21 juill. 1862, Dall. Per. 1862 I 419, 419-420. 
Vol. 7, No. $4 \quad$ Lytvynenko: The Rise of the French Doctrine of Informed Consent...

\section{United Kingdom}

Slater v Baker \& Stapleton, 2 Wils. K. B. 359, 360-363 (1767).

\section{United States of America}

Salgo v. Leland Board etc. Trustees, 154 Cal. App. 2d 560, at p. 578-579 (1957) [Civ. No. 17045. First Dist. Div. One. Oct. 22, 1957]. 